\title{
SIGLEC9 Gene
}

National Cancer Institute

\section{Source}

National Cancer Institute. SIGLEC9 Gene. NCI Thesaurus. Code C123869.

This gene is involved in sialic acid binding and cell adhesion. 